\title{
Исторический опыт
}

\section{нациестроительства в Якутии \\ (1922 - конец 1930-х гг.)}

Борисов Андриан Аббанасьевич д-р ист. наук, приглашенный исследователь, Санкт-Петербургский Институт истории РАН; гл. науч. сотр., Институт гуманитарных исследований и проблем малочисленных народов Севера (Якутск, Россия)
Время с 1922 г. по конец 1930-х гг. было эпохой интенсивного глобального развития наций и национализма. Какие бы ни давались определения нации ${ }^{1}$, но в одном безусловно сходится большинство исследователей в признании универсального характера тенденции соединения этнокультурной общности с последствиями модернизации (индустриализацией, урбанизацией, формированием гражданского общества), приводящей, в свою очередь, к стремлению совместить этнические и политические границы волевыми целенаправленными действиями этнических и национальных элит.

Кризис и распад многонациональных империй (Австро-Венгерской, Германской, Османской и Российской) в результате Первой мировой войны и серия революций вызвали новый виток в развитии национализма и национальных движений в Европе и Азии. В Центральной, Юго-Восточной Европе и в Западной Азии это привело к возникновению множества небольших национальных государств ${ }^{2}$. Кризис мировой колониальной системы стимулировал волну аналогичных процессов в других частях света.

Особый пример дает распад Российской империи, где возникла иная ситуация. Ни революционные потрясения, ни ожесточенная Гражданская война, усугубленная 
иностранной интервенцией, не помешали к 1922 г., всего за несколько лет, фактически возродиться на прежнем месте новому многонациональному государству - СССР. Сложилась мощная федерация народов бывшей Российской империи, которая сумела устоять и вновь выдвинуться в число ведущих мировых держав. Высокий научный интерес вызывает именно этот опыт нациестроительства, позволивший, с одной стороны, сохранить этнокультурное многообразие, а с другой - сформировать суперэтническую общность, которую пытались идентифицировать как советский народ.

Данная проблема связана в первую очередь с той политикой, которую проводило государство в отношении народов, входивших в его состав. Советский Союз унаследовал от Российской империи не только территорию и почти то же количество народов, но и экономическую базу, культурные традиции, наконец, элементы разрушенной, но до конца не уничтоженной государственной системы $^{3}$. Поэтому большевистскому правительству пришлось продолжать осуществлять - вначале по инерции, а потом уже осознанно - мультикультурную модель этноконфессиональной политики Российской империи. Эта модель включала в себя веротерпимость, культурную автономию и систему косвенного управления нерусскими народами. Многие из них обладали особым статусом инородцев, которые платили ясак, несли менее обременительные повинности, были освобождены от военной повинности, имели самоуправление и сохраняли этническую территорию проживания ${ }^{4}$.

Правительство гибко реагировало на малейшие этнические конфликты, нередко возникавшие на имперском пространстве; при этом власти сочетали силовые и мирные средства, но чаще всего предпочтение отдавали последним ${ }^{5}$. Этнические элиты были инкорпорированы в систему государственного управления и привлекались на правах союзников к военной службе, причем некоторые из них рассматривали службу как привилегию.

Среди инородческого населения заметную долю занимали тюрко-монгольские народы, имевшие особую полифункциональную политико-потестарную и социальную улусную организациюб ${ }^{6}$ также хорошо вписывавшуюся в имперскую систему косвенного управления. Хотя улусы имели кочевой характер, строгая иерархичность внутреннего управления (основанная на этногонической генеалогии) и гомогенность хозяйственного образа жизни создавали предпосылки для эффективного управления ими.

Якутия к изучаемому времени представляла собой обширную территорию бывшей Якутской области, превышавшую 4 млн км². Якуты - доминировавшая численно этническая группа (по переписи 1926 г. - 235926 чел., или $82,7 \%$ удельного веса от общей численности населения, русские - 30156 чел.

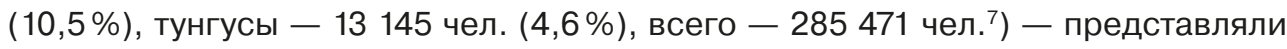
собой аграрную общность. Подавляющая часть якутов занималась скотоводством, ориентированным на рынок. Среди занятых животноводством доля

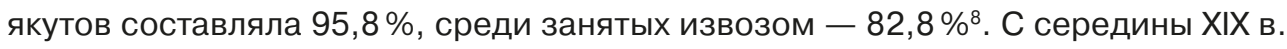
за счет почтово-трактового извоза, поставок на прииски сельхозпродукции интенсивность внутриэтнических связей заметно повышается. 
Разбросанность относительно немногочисленного народа и полуоседлый образ жизни привносили специфику в этническое развитие якутов. Якутия делилась на улусы, причем в десяти улусах Якутского округа проживало почти две три якутского населения (126 432 чел.). Из трех других групп значительной была вилюйская группа из семи улусов (72 050 чел.). Две другие - северная, из пяти улусов (бассейны р. Яны, р. Колымы и других северных рек), и олекминская, из одного улуса (устье р. Олекмы), - численно были маленькими: 10002 чел. и 8651 чел. соответственно ${ }^{9}$. Тем не менее такая география, когда места расселения соединялись трактами и судоходными реками, формировала довольно устойчивые представления об относительно единой этнической территории.

Из трех связующих нацию форм отношений, по М. Хроху ${ }^{10}$, первая форма память об общем прошлом - получила заметное развитие у якутов. Речь идет о переселенческой концепции происхождения всех якутов от первопредков Омогоя и Элляя и их потомков ${ }^{11}$. У всех групп якутов были распространены подобные представления. Это было классическое номадическое улусное родословие (как и у всех тюрков и монголов), но дополненное событийным фактором - переселением в незапамятные времена патриархов якутского народа с юга. Более того, якутская эпическая сага (олонхо) была развита представлениями народа о повелителе всех якутов - кангаласском улусном главе Тыгыне.

Второй тип отношений, связывающих нацию, - плотность и интенсивность языковых и культурных связей внутри этнической группы - имел следующие особенности. Все якуты говорили на одном языке, к тому времени уже

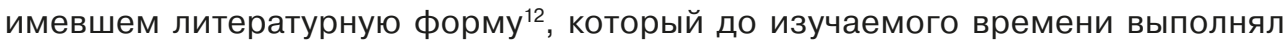
также роль языка межнационального общения. В Якутии были распространены не только шаманистические верования - все якуты уже на протяжении более 100 лет были крещены в православную веру, что также сплачивало их этническое единство. По сравнению с якутами, у бурят, культурно и типологически близкого народа, ситуация осложнялась большей поликонфессиональностью (заметным влиянием буддизма), а также наличием нескольких административных и культурных центров, почти равнозначных для формировавшейся бурятской нации и расположенных в Прибайкалье (Иркутск) и Забайкалье (Верхнеудинск, Чита).

Город Якутск был единственным крупным населенным пунктом на всю область, отвечавшим критериям города; одновременно он представлял собой административный центр, торговый перевалочный пункт между тихоокеанскими воротами России - портами Охотского моря, сибирскими городами и европейской частью России. Якутская ярмарка была важным информационным центром, куда съезжалось все якутское торгующее население; туда же свозился ясак, там совершались все деловые сделки. Уровень урбанизации

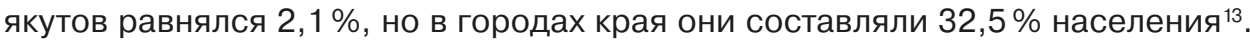

Предпосылкой третьего типа отношений - концепции равенства всех членов группы, организованной в гражданское общество, - были относительная однородность якутского общества и его внутренняя социальная мобильность. К середине 1920-х гг. большинство населения составляли середняки $(68 \%)^{14}$. В среднем на одно хозяйство приходилось 8,4 головы крупного рога- 
того скота и 3,1 головы лошадей ${ }^{15}$. Это был край мелких и средних собственников-скотовладельцев. Элитой общества считались тойоны, тесно связанные с остальным населением кровнородственными, клановыми, деловыми отношениями. Переход из малоимущих слоев общества в число купцов или тойонов мог осуществиться в течение жизни одного-двух поколений.

K началу XX в. возникает якутская национальная интеллигенция. Если по переписи 1897 г. грамотных среди якутов было 0,7\%, то за четверть века до описываемого периода уровень образованного якутского населения заметно возрос. К 1917 г. доля грамотных по области достигла 5-10\%, а в 1926 г. - 16\% (якутов в сельской местности - 12,8\%) ${ }^{16}$. По данным С. Н. Горохова, в 1917 г. численность якутской интеллигенции оценивалась в 260 чел. ${ }^{17}$ Внутри нее не было единства. Союз истинно русских якутов, возглавлявшийся М. С. Шеломовым, выступал за сохранение монархии и прежних устоев государства. Значительную часть интеллигенции составляли либералы - В.В.Никифоров, Г. В. Ксенофонтов, С. А. Новгородов. К левым примыкали М. Т. Попов, Д. А. Кочнев и др. Наконец, большевиками были М. К. Аммосов, П. А. Ойунский, И. Н. Барахов, С. М. Аржаков и др. Многие из них получили высшее образование в России в период с 1900 по 1917 г., т. е. в революционные годы, и вынесли оттуда широкую палитру политических взглядов. В.В.Никифоров писал: «Обрусение инородцев и слияние их с русскими... возможно лишь при условии распространения между ними грамотности, экономического развития и усвоения ими культурной жизни. Все это может быть достигнуто... путем предоставления инородцам такой формы самоуправления, которая дала бы возможность объединить интересы всего якутского племени» ${ }^{18}$. Мнение самого видного представителя якутской интеллигенции весьма показательно, ведь в нем отразились главные веяния эпохи.

Интеллектуальная элита имела не только политические организации, но и возможность публиковать свои идеи на якутском языке на основе кириллицы. С 1907 г. выходила общественно-политическая и литературная газета «Якутский край» («Якутская жизнь», «Якутская мысль»), издававшаяся на русском и якутском языках ${ }^{19}$.

Неудивительно, что события Февральской революции быстро привели к созданию в Якутии таких элементов гражданского общества, как самоуправление, - областное земство, Якутский национальный комитет, культурно-просветительское общество «Саха аймах». Отметим также решающую роль ссыльных эсеров и социал-демократов в первые месяцы революции, когда они возглавили Якутский комитет общественной безопасности.

Земская автономия в Якутии вызвала негативную реакцию в административных центрах Сибири и в столице. Она была расценена как сепаратизм²0. В результате летом 1918 г. ревкомом Иркутска послал в область отряд красных, и произошло первое кратковременное установление советской власти.

Правительство А. В. Колчака (1918-1919) в целом благосклонно отнеслось к деятельности Якутского земского управления во главе с В. В. Никифоровым, поддержав некоторые его начинания. 
Фронты Гражданской войны не протянулись до Якутии, но эхо далеких боев докатилось и сюда в виде незаконных арестов, несанкционированных судов и расстрелов, не говоря уже о случаях насилия и грабежей.

Успех большевиков, вновь пришедших к власти в Якутии в декабре 1919 г., был обусловлен принципами национальной политики Советского государства, закрепленными в Декларации прав народов России от 15 ноября 1917 г. и Конституции РСФСР от 10 июля 1918 г. По мнению правоведов, предоставленное право на национальное самоопределение было теоретическим, так как ограничивалось принципом демократического централизма ${ }^{21}$. Тем не менее провозглашение самоопределения в первые годы имело большое пропагандистское значение.

Э. Геллнер связывает развитие национализма с процессом соединения государства и «национальной культуры»22. Большевистскому правительству пришлось иметь дело не только с классовыми и политическими противниками, но и с национализмом. Временное правительство и предводители белых затягивали вопрос о национальном самоопределении, а борьба за единую и неделимую Россию усиливала национальные движения на всем многонациональном пространстве бывшей империи, что рождало новые значительные проблемы.

Большевистское правительство использовало поддержку национальных устремлений к сохранению культурной самобытности и к формированию политических ассоциаций на этнической основе. Не случайно пример предоставления независимости Финляндии и Польши сыграл важную роль в успехах красных. Поэтому правительству Советской России, а затем и СССР крайне необходимо было участвовать в процессе нациестроительства совместно с этническими и национальными элитами многочисленных народов от западных границ до самых отдаленных рубежей на востоке.

Почти сразу же встал вопрос об образовании Якутской автономии, который был решен не сразу ${ }^{23}$.

Имелось четыре варианта: культурно-национальная автономия (группа якутской интеллигенции во главе с Г. В. Ксенофонтовым), Якутская область (Сиббюро ЦК РКП(б)), «буферное» государство (Якутское губбюро РКП(б) во главе с Г.И. Лебедевым), Якутская автономная республика (группа молодых якутских большевиков во главе с М.К. Аммосовым). С большим трудом реализовался последний. Началась новая эпоха в этнической истории якутов, а с ней - восходящая фаза нациестроительства.

16 февраля 1922 г. Президиум ВЦИК поручил Наркомнацу разработать Положение о Якутской АССР. Однако НКВД и Наркмофин были несогласны с этим: первый считал разработку данного вопроса своей прерогативой, а второй ссылался на экономию средств ${ }^{24}$. Дальше тянуть было опасно, потому что 2-12 марта 1922 г. в с. Чурапча состоялся съезд народов Якутии, в советской историографии называвшийся «контрреволюционным сборищем». На нем было образовано Временное областное якутское народное управление, ориентированное на борьбу против большевиков, во главе с бывшим делегатом VIII съезда ВЦИК РСФСР, представителем Якутской губернии в Сибревкоме Г. С. Ефимовым ${ }^{25}$. Это был один из тех интеллигентов, которых в 1921-1922 гг. толкнула 
в ряды якутского повстанчества большевистская политика жесткой централизации (военный коммунизм). Именно их имел в виду М. К. Аммосов, когда писал, что после «довольно суровой ликвидации последнего белогвардейского заговора» введение автономии крайне необходимо, «ибо движение, идущее под флагом национального освобождения, все ширится и ширится, захватывая бедняцкие и даже коммунистически настроенные интеллигентские элементы»²6.

Все описываемое происходило в условиях запоздало разгоравшейся гражданской войны в крае, во многом спровоцированной руководством области во главе с Г.И. Лебедевым, не намеревавшимся отходить от принципов политики военного коммунизма и призывавшим расправляться с повстанцами как с бандитами и националистами. Такой пагубной политике был положен предел с прибытием в Якутию весной 1922 г. группы видных военных и партийных деятелей, таких как С. Ю.Широких-Полянский, К. К. Байкалов, И. Я. Строд и др., которые поддержали позицию местных якутских большевиков.

Несмотря на ведомственные разногласия, Положение об автономии было разработано, и Президиум ВЦИК 27 апреля 1922 г. принял историческое Постановление об образовании ЯАССР 27 . В июне 1922 г. образовался СНК ЯАССР во главе с П.А. Ойунским. В состав правительства вошли также беспартийные якутские интеллигенты.

В соседней Бурятии уже к 1919 г. цель достижения автономии бурят была достигнута в форме официального признания Бурятского национального комитета советской властью и правительством Забайкальской области (глава - атаман Семенов). Несмотря на это, дальнейшее развитие национального самоопределения бурятского народа пошло по пути реализации идеи об объединении монголоязычных народов. Завершение Гражданской войны в пользу Советов сняло идею с повестки дня, но образование буферной Дальневосточной республики (далее - ДВР) раскололо бурятское население 28 . В Южной Сибири родственные якутам по языку тюркские народы в течение 1922-1930-х гг. получили разные статусы в Союзном государстве: алтайцы и хакасы - статус автономной области, а шорцы - статус национального района. Одновременно, как и в случае с бурятами, на Втором съезде советов Хакасского уезда по причине недостаточности уездной формы национального самоопределения был поднят вопрос об объединении сибирских тюрков в федеративную республику ${ }^{29}$. По-видимому, отдаленность Якутии и большая этническая гомогенность ускорили (по сравнению с названными регионами) введение здесь республиканской формы автономии.

Официально разграничение полномочий между правительствами РСФСР и ЯАССР произошло только с изданием Декрета ВЦИК и Конституции ЯАССР в 1926 г. ${ }^{30}$ До 1927 г. развитие государственности республики (впрочем, как и других автономных республик) шло фактически самостоятельно, без контроля со стороны центральных властей ${ }^{31}$.

С образованием республики возник вопрос о границах; спорными были следующие территории: часть Киренского уезда, Сунтаро-Олекинский улус, Южная Якутия (Алдано-Тимптонский район), Алдано-Майский улус, часть Колымского округа и побережье Охотского моря. На первые две претендовали 
власти Иркутской губернии, на третью - Амурской губернии, а на последние две - вначале ДВР, а потом Хабаровск ${ }^{32}$. Спор продолжился до начала 1930-х гг.

Решение о границах ЯАССР было окончательно принято на Президиуме ВЦИК 10 мая 1931 г. Почти все претензии были удовлетворены: в состав республики не вошло только охотское побережье ${ }^{33}$. Успешность в решении территориальных проблем в Якутии по сравнению с другими регионами заключалась в относительной компактности расселения якутов и в значительной степени их консолидированности. Например, в Коми основной сложностью была проблема объединения коми, разбросанных в различных регионах и разделенных границами, доставшимися от прежней имперской территориально-административной системы (Архангельская, Пермская и Вятская губернии) ${ }^{34}$.

По мнению Е. П. Антонова, «практическая реализация принципа самоопределения народов... обострила старые дореволюционные и породила новые национальные противоречия в полиэтничной среде» ${ }^{35}$. Справедливо и то, что не последнюю роль сыграло роковое Постановление ЦК ВКП(б) от 9 августа 1928 г. «О положении в Якутской организации» ${ }^{36}$. Кроме того, именно в этот период, когда происходило установление административных границ, в большей степени учитывался экономико-географический фактор.

20 марта 1924 г. вследствие формирования системы союзных органов власти Наркомнац РСФСР был ликвидирован, и при Президиуме ВЦИК появились представительства автономных республик, в том числе и ЯАССР, которые также подчинялись отделу национальностей при Президиуме ВЦИК ${ }^{37}$. Возник своеобразный эффект матрешки: федеративные отношения между РСФСР и ЯАССР были усложнены надстроившимся над ними высшим союзным уровнем государственных отношений.

При разграничении полномочий между союзными и местными органами власти победили сторонники централизации. Способность отстоять интересы республики встала в зависимость от конституционных механизмов (в случаях столкновений ее интересов с интересами центра), а также от веса представительства республики в союзных органах власти. Впоследствии произошли унификация республиканских конституций, усиление контрольных функций центральных органов власти и истребление местных элит, претендовавших на самостоятельность (или даже заподозренных в этом) ${ }^{38}$. Так, во второй половине 1920-х гг. наметилась тенденция перехода ко второй фазе нациестроительства - фазе пересмотра статуса национальной автономии.

В декабре 1925 г. группа беспартийных интеллигентов неудачно выдвигала П.В. Ксенофонтова делегатом IV Всеякутского съезда Советов с намерением включить в повестку вопрос о выходе ЯАССР из состава РСФСР и вхождении в СССР ${ }^{39}$. Ноябрьское 1926 г. совещание членов ВЦИК и ЦИК СССР, созванное по инициативе отдела национальностей при Президиуме ВЦИК в Москве, поставило вопрос об ущемлении прав автономий на фоне централизации управления. Хотя предложение упразднить РСФСР и ввести все автономии в СССР не прошло, было предложено укрепить позиции последних путем ввода национальных работников в центральные органы власти ${ }^{40}$. 
Вместе с тем районирование 1929-1930 гг., проведенное в ЯАССР, помимо принципов, обеспечивавших хозяйственную однородность, единообразие управления, укрупнение местных советов, учитывало национальный состав территории и ее географические признаки ${ }^{41}$. Данное мероприятие сформировало сравнительно эффективную конфигурацию одной из крупных национальных республик на Северо-Востоке. Напротив, в отношении Бурят-Монгольской АССР в рассматриваемый период были проведены мероприятия, заметно ослабившие ее как национальное образование. Помимо укрупнения районов внутри республики произошло ее расчленение: четыре аймака были переданы в состав Иркутской области, два - в состав Читинской области. Такие меры были продиктованы внешнеполитическими факторами - угрозой войны с Японией ${ }^{42}$.

Как считают специалисты, «Советское государство вернулось к старым дореволюционным методам привлечения нерусских элит в органы управления и административные структуры национальных регионов», чему служила и проводимая политика коренизации ${ }^{43}$. Еще 28 июня 1921 г., выполняя решение X съезда РКП(б) «Об очередных задачах партии в национальном вопросе», Наркомнац РСФСР разработал документ «О разработке языков коренного населения автономных республик», а СНК ЯАССР 12 августа 1922 г. своим Постановлением ввел в школах первой ступени с преобладанием якутских детей преподавание на первом году обучения исключительно на якутском языке ${ }^{44}$.

IV сессия ЯЦИК в сентябре 1923 г. приняла Постановление о якутизации государственных служащих. Причем за отказ учить якутский язык они могли быть уволены с работы ${ }^{45} .23$ марта 1925 г., согласно Постановлению ЯЦИК, аналогичные репрессивные меры были распространены на производстве, за исключением учреждений финансового, военного, почтово-телеграфного ведомств. Президиум ЯЦИК 9 декабря 1929 г., констатировав «отставание в деле якутизации» (хотя среди руководящих работников доля владеющих якутским языком составила $37,4 \%$, а численность якутов в государственных органах управления - 17,1\%), постановил уже к 1 февраля 1930 г. якутизировать госаппарат на $50 \%$ и перейти на смешанное делопроизводство ${ }^{46}$. По другим же данным, уже в 1926 г. в Якутской АССР из 176 чел. руководящего персонала 105 чел. были якутами ${ }^{47}$. Все эти мероприятия проводились без ведома федеральных и союзных органов власти.

С политикой коренизации (якутизации) было тесно связано создание массовой письменности на якутском языке. Предпосылки к этому сложились в дореволюционный период. В 1917 г. выпускник Санкт-Петербургского университета С. А. Новгородов создал на основе системы МФА (Международного фонетического алфавита) якутскую письменность, хорошо принятую населением, несмотря на споры среди общественности, - некоторые представители интеллигенции выступили против (например, А. Е. Кулаковский, сторонник письменности на основе кириллицы). Подобные процессы имели всесоюзное значение. 
По данным А. Миллера, в течение 1920-1930-х гг. языковая политика в СССР эволюционировала от политики коренизации (когда кириллица «воспринималась как один из символов русского империализма и русификации» и взамен ее вводилась латиница) в сторону пересмотра латинизации в 1932 г. За несколько лет 66 языков в СССР были переведены на кириллицу, а часть языков, в том числе русский, готовились к переводу на латиницу. Но уже в 1930 г. Политбюро приостанавливает данный процесс ${ }^{48}$.

Середина 1930-х гг. была периодом обострения политической борьбы. В эпицентр ее попали и сторонники латинизации. Обвинения в национализме, усугубленные обвинениями в пантюркизме, стали важнейшим аргументом в этой борьбе. В конце концов, в 1938 г. предпочтение было отдано кириллице ${ }^{49}$, в том числе для якутской письменности.

Возобладала традиционная прагматичная линия. Опыт развития письменности в Российской империи не прошел даром. Успехи миссионеров, апробация в форме публикаций на основе кириллического алфавита, учет внешнеполитических тенденций сыграли решающую роль в подобном выборе.

Тем не менее, несмотря на издержки частой перемены политического курса за столь короткий срок, главным результатом было обретение якутами массовой письменности. Так, всего за 13 лет (с 1922 по 1935 г.) вышли в свет 835 книг на якутском языке. Общий тираж этой печатной продукции оценивается почти в 2,5 млн экз. ${ }^{50}$ В числе прочего в эти годы были растиражированы фольклорные сборники ${ }^{51}$, куда вошли циклы легенд о прародителях Эллее и Омогое, а также об их властном потомке Тыгыне. Эти фольклорные произведения были систематизированы, с тем чтобы придать им статус устной истории якутского народа.

Большевистская трактовка национального самоопределения ставила его в зависимость от социально-классового контекста и использовала как лозунг для достижения власти. Большинство лидеров большевиков стояли на принципах пролетарского интернационализма и сохранения государственного единства. Был взят однозначный курс на сближение и слияние наций с одним общим языком ${ }^{52}$.

Национализм, породивший различные формы национального самоопределения, не мог не столкнуться с этими принципами, завоевавшими популярность не только среди русскоязычного большинства, но и в национальных регионах. Именно данными тенденциями объясняется логика репрессий в отношении любых категорий национализма конца 1920-х гг. и второй половины 1930-х гг. Начало было положено инцидентом с лидером татарских национал-коммунистов М. Х. Султан-Галиевым ${ }^{53}$. Среди тюркских народов Южной Сибири еще в середине 1920-х гг. заподозренные в сепаратизме и объявленные националистами лидеры алтайцев Г. И. Чорос-Гуркин, В. К. Манеев, Г. М. Токмашев, Л. М. Эдоков, И. С. Алагызов, хакасов - Г.И. Итыгин, щорцев Я. К. Тельгереков стали подвергаться преследованиям ${ }^{54}$.

Как считают якутские ученые, в Якутии репрессивный механизм был запущен в 1927 г. статьей А. М. Аршаруни «О борьбе с националистической идеологией» в журнале «Коммунистическая революция» ${ }^{55}$ с подачи молодых пролетар- 
ских деятелей якутской литературы С. Р. Кулачикова-Элляя, А. А. Иванов-Кюндэ, начальника Главлита республики С. Г. Потапова, выступивших с резкой критикой творчества буржуазных националистов В.В. Никифорова, А. Е. Кулаковского, А. И. Софронова, Н. Д. Неустроева ${ }^{56}$. Так называемый заговор безработных Добдукова и Сергеева, недовольных возрождением частной торговли, амнистией беспартийной интеллигенции и высокими зарплатами руководителей республики (весна - лето 1927 г.), спровоцировал выступление партии якутских «конфедералистов» - сторонников расширения статуса ЯАССР во главе с П.В.Ксенофонтовым. В результате раскрытия заговора местное ОГПУ арестовало многих видных интеллигентов - В. В. Никифорова, А. И. Софронова, И. Ф. Афанасьева, А. И. Говорова, П.И. и В. М. Оросиных и др. ${ }^{57}$

Специальная комиссия ЦК РКП(б) в составе Н. А. Кубяка, Г. Г. Ягоды, И. С. Уншлихта, а затем и ЦК ВКП(б) в постановлении «О положении в Якутской организации» квалифицировали события 1927 г. как «бандитизм». Кроме того, руководство Якутского обкома было обвинено в попустительстве националистически настроенной якутской интеллигенции. В феврале 1928 г. после скоротечного следствия осудили 191 чел., из которых 64 чел. расстреляли ${ }^{58}$. Большая группа руководителей республики была отозвана на работу в Москву, и им было запрещено возвращаться на родину в течение 10 лет. Из 49 членов ЯЦИК в его составе оставили только 13 чел. ${ }^{59}$ В эпоху нациестроительства в Якутии произошел переход ко второй фазе, т. е. движению в сторону централизации и усечения автономии.

До середины 1930-х гг. местная элита, несмотря на репрессивные меры конца 1920-х гг. и насильственное разобщение, еще сохраняла силу. Инерция предыдущего периода нациестроительства продолжалась, пока не была прервана физическим уничтожением видных ее представителей М. К. Аммосова, И. Н. Барахова, Х. П. Шараборина, С.Н.Донского-ІІ, К. О. Гаврилова, С.В.Васильева, П.А. Ойунского и многих других. По политическим процессам в 19351940 гг. в Якутии проходило 3030 чел., из которых 134 были приговорены к расстрелу60. Параллельно началось свертывание элементов самостоятельности республики, достигнутых в 1922-1927 гг. Так, Конституция 1937 г. уже не гарантировала автономный статус ЯАССР, требовала жесткого соответствия законодательству федерации; республика «действовала в режиме местного управления» 61 .

В первые годы советской власти шаманство сохраняло свое положение в якутском обществе как профессия, необходимость которой признавалась обществом, и фактически выполняло функцию культурного индикатора ${ }^{62}$. По некоторым данным, в 1920-1930-е гг. было выявлено от 300 до 400 шаманов ${ }^{63}$ значительная цифра для небольшого народа, равная численности якутской интеллигенции.

В середине 1920-х гг. Президиум ЯЦИК и СНК ЯАССР приняли законодательные акты, определившие направления и методы борьбы с шаманством ${ }^{64}$. В ноябре 1924 г. «Инструкция» Наркомата юстиции ЯАССР приравняла действия 
шаманов к контрреволюционной деятельности с целью дискредитации в глазах населения ${ }^{65}$.

Самое жестокое преследование шаманов началось на рубеже 19201930-х гг. во время проведения уравнительной земельной реформы, когда шаманы с их семьями лишались земельных участков. Также, согласно Постановлению СНК СССР от 21 мая 1929 г. $^{66}$ и Постановлению Президиума ЯЦИК от 25 июня 1930 г. ${ }^{67}$ о раскулачивании, шаманы как служители религиозных культов лишались избирательных прав. Кроме того, местные власти по своей инициативе выселяли их из наслегов, конфисковывали имущество, исключали их детей из школы, увольняли с работы и т. д. ${ }^{68}$

Интересно, что органы ОГПУ - НКВД практически не привлекали шаманов к судебной ответственности и не преследовали их ${ }^{69}$. Это говорит о том, что местные власти и население сами принимали активное участие в борьбе с шаманством. В качестве форм и методов такой борьбы использовались антирелигиозная пропаганда, лекции, карнавальные шествия, политсуды ${ }^{70}$; привлекались национальная интеллигенция, общество “Саха омук», учащаяся молодежь, общественные организации ${ }^{71}$. В результате к концу 1930-х гг. шаманство прекратило свое существование ${ }^{72}$, в формировавшемся теле якутской нации ему не нашлось места. В отличие от якутского опыта, в Бурятии религиозный фактор играл важную роль как одна из форм национального самоопределения бурят. В 1919-1922 гг., например, существовало довольно влиятельное теократическое движение во главе с Л.-С. Цыденовым, охватившее тысячи людей ${ }^{73}$.

Несколько иначе обстояло дело с православием в Якутии. Несмотря на повсеместное осуществление Декрета от 20 января 1918 г. «Об отделении Церкви от государства и школы от Церкви ${ }^{74}$, довершившего начинания Временного правительства, некоторые органы и учреждения Якутской епархии продолжали существовать до конца 1920-х гг. Кроме того, еще в 1919 г. лица духовного звания насчитывали в области 430 чел. ${ }^{75}$, т. е. оставались значительной группой населения Якутии, такой же политически и культурно подготовленной, как и местная интеллигенция.

Организованная антирелигиозная пропаганда в республике началась только с осени 1927 г. До этого же Постановление Бюро Якутского обкома РКП(б) от 21 апреля 1925 г. $^{76}$ заявляло о перегибах и запрещало изъятие храмов при наличии коллектива верующих; в 1926 г. было признано нецелесообразным организовать «Общество безбожников» - его разрешили только «в виде опыта» в Якутске. В 1928 г. проходили неоднозначные обсуждения в профсоюзных организациях о судьбе храмов, особенно Свято-Троицкого кафедрального собора (весной 1929 г. его все же закрыли). Последний действующий Никольский храм закрыли 23 октября 1939 г., хотя в 1933 г. в Якутске был открыт молитвенный дом «староцерковников» 77 .

Бюро Якутского обкома в специальных списках с 1925 г. фиксировало лиц, участвовавших в коллективах верующих (среди них были и якуты), допуская их трудоустройство. Ситуация изменилась только после того, как с 1929 г. ВЦИК и СНК РСФСР, союзные органы власти повели жесткую антирелигиозную политику, что отразила и Конституция 1936 г. $^{78}$ 
Перечисленные факты говорят о том, что руководство республики на первой фазе нациестроительства оставляло (хотя и временно) определенное место православию в своем нациепроекте.

$* * *$

Если в начале столетия обширной территорией Якутии руководило около 1200 управленцев, из которых инородцы составляли около 900 чел. (чиновники областной администрации, улусные головы, старосты и старшины, писари) ${ }^{79}$, то к 1939 г. насчитывалось 8164 руководящих работников государственных и партийных органов власти, различных учреждений, в том числе якутов - 3866 чел. $(47,4 \%)^{80}$. Таким образом, бюрократия численно выросла и превратилась в заметный слой общества.

По переписи 1939 г. общая численность ЯАССР составила 413198 чел., увеличившись по сравнению с последней переписью на 127727 чел. (на $44,7 \%$, или в 1,5 раза). Численность якутов снизилась до 56,5\%, всего их стало 233173 чел., что было меньше на 2753 чел. (на 1,1\%), чем в 1926 г. Напротив, увеличились численно другие этнические группы (их доля возросла до 40,1\%). Например, численность русских составила 146741 чел. (35,5\% от всего населению республики). В основном рост дало промышленное развитие Южной Якутии ${ }^{81}$. Для сравнения: доля якутов-инородцев до революции 1917 г. составляла 870 на 1000 жителей области и была самой высокой в России ${ }^{82}$.

Удельный вес горожан республики вырос с 5,3\% до $27 \%$. Доля русских среди них возросла с 53,9\% (27,2\% ко всему русскому населению республики) до $75,9 \%$ (57,7\%), а якутов - уменьшилась с 32,5\% до 13,9\% (хотя процент к общему якутскому населению, напротив, увеличился с 2,1\% до 6,6\%) ${ }^{83}$. Таким образом, за короткий срок структура якутского общества стала приобретать современный вид со своей светскостью, бюрократией, урбанизирующимся населением, что облегчалось относительной однородностью населения.

В изучаемый период отчетливо выделяются две фазы нациестроительства в Якутии: 1922 - конец 1920-х гг.; конец 1920-х гг. - конец 1930-х гг. Опыт фактически независимого развития Якутии в 1922-1927 гг. был двояк: с одной стороны, укрепилась культурная автономия за счет развития якутского языка и политики коренизации, а с другой - еще более обострилась политическая борьба, на вершине которой встали национальные вопросы.

Стремительная коренизация с репрессивными элементами и более всего выдвижение претензий на повышение статуса республики до союзного на первой фазе нациестроительства вызвали резко негативную реакцию у федеральных и центральных партийных властей. Официально признанная доктрина подчинения национальных интересов социально-классовому началу - пролетарскому интернационализму - столкнулась с якутским национализмом новой формации.

Развитие якутской письменности и литературы получило мощный толчок и за короткий срок достигло массового уровня, что позволило быстро ликвидировать неграмотность. За изучаемый период произошло двукратное изменение 
официально принятой письменности: первое совпало со сменой фаз якутского нациестроительства (1929), второе знаменовало начало утверждения новых начал в этноконфессиональной политике страны. Названные стороны якутского нациестроительства соответствовали общесоюзным тенденциям в других национальных республиках и областях, чего нельзя сказать об административно-территориальном оформлении нации.

Если компромисс в отношении границ ЯАССР стал одним из образцов оптимального решения территориального разграничения, учитывавшего как географические, так и этнокультурные особенности, то аналогичные процессы, например, у коми, а особенно у тюрков Южной Сибири и у бурят происходили с заметным ущемлением национальных интересов названных народов.

Политика в отношении религии характеризовалась тем, что с шаманством - культурным индикатором якутов - было покончено в кратчайшие сроки, фактически на первой фазе нациестроительства. С православием же дело обстояло несколько иначе. Именно в годы автономного развития республики наблюдалось терпимое отношение к Церкви и верующим. Перелом наступил под влиянием общесоюзной антирелигиозной компании на рубеже 1920-1930-х гг.

На стартовых позициях относительно однородная внутренняя структура якутского общества стала обретать черты гражданского общества: всеобщая грамотность, приобщение широких масс к управлению, еще бо́льшая социальная мобильность. Ускоренное создание слоя промышленных рабочих из числа якутского населения было прервано в результате политических репрессий, но стало позитивным прецедентом.

Формирование якутской нации оказалось успешным благодаря имевшимся предпосылкам (общность языка, относительная однородность населения), но сопровождалось непрекращавшейся борьбой с национализмом со стороны сибирских и центральных властей. Форсирование политических процессов сыграло роковую роль, и последовавшие массовые репрессии национальных кадров Якутии имели под собой общую подоплеку с общесоюзными тенденциями централизации и усиления личной власти И. В. Сталина. По его мнению, развитие национальной культуры народов СССР должно было подчиняться интересам и потребностям пролетарской диктатуры и стать общим для всех по своему содержанию ${ }^{84}$.

Лишение автономного статуса республики, переход от политики привлечения национальной интеллигенции в период нэпа к гонениям на нее по обвинению в буржуазном национализме, свертывание «коренизации» и национального обучения при приоритете русского языка, переход на кириллицу, вытеснение религии ${ }^{85}$ стали вехами на пути реализации нового этапа национальной политики Советского государства.

За экстремально короткий срок была предпринята уникальная попытка преобразования силой государства и волевыми усилиями этнической интеллектуальной элиты одной из заметных этнокультурных общностей северовостока страны. Все издержки и жертвы этого процесса можно объяснить краткосрочностью и мобилизационным характером реализации данного проекта. 
1 См., напр.: Броллей Ю. В. Этносоциальные процессы: теория, история, современность. М., 1987; Селенов Ю.И. Социально-исторические организмы, этносы, нации // Этнографическое обозрение. 1996. № 3. С. 3-13; Нации и национализм / Б. Андерсон, О. Бауэр, М. Хрох и др.; пер с англ. и нем. Л. Е. Переяславцевой, М. С. Панина, М. Б. Гнедовского. М., 2002. С. 18, 56-60, 88, 122, 253-254, 257, 365; Ачкасов В.А. Этнополитология. СПб., 2005. С. 86-105; Тишков В. А. О нации. URL: http://www.valerytishkov.ru/cntnt/publikacii3/publikacii/o_nacii1.html (дата обращения: 23.05.2017).

2 См. об этом: Нации и национализм... С. 11.

3 См. об этом: Власть и реформы. От самодержавной к Советской России. М., 2006. С. 646.

4 См. об этом: Borisov A. The political status and ethnic identity of Siberian nomadic "aliens" in the first half of the $19^{\text {th }}$ century // Northeast Asian Studies. 2014. Vol. 18. P.1-7.

5 См., напр.: Kanпелер A. Россия - многонациональная империя. М., 2000. С. 18.

6 См. об этом: Борисов А. А. Улус как универсальная форма политической и общественной самоорганизации тюркских и монгольских народов // Eurasian Nomadic Pastoralism History, Culture, Environment. Sendai, 2016. P. 123-134.

7 Данные приводятся по: Игнатьева В. Б. Национальный состав населения Якутии (этно-статистическое исследование). Якутск, 1994. С. 32-33; Федорова E. Н. Население Якутии: прошлое и настоящее (геодмеографическое исследование). 2-е изд. Новосибирск, 1999. С. 84.

8 Данные по: Аргунов И. А. Социальное развитие якутского народа (историко-социологическое исследование образа жизни). Новосибирск, 1985.

9 Данные по: Соколов М. П. Якутская губерния по переписи 1917 года. Иркутск, 1922. C. 84-85, XX-XXI.

10 Нации и национализм... С. 122.

11 См., напр.: Ксеноббонтов Г.В. Эллэйада. М., 1977.

12 См. об этом: Новгородов С.A. К вопросу о говорах в якутском языке // Первые шаги якутской письменности: статьи и письма. М., 1977. С. 36; Воронкин М. С. Диалектная система языка саха: образование, взаимодействие с литературным языком и характеристика. Новосибирск, 1999. С. 34-35.

13 Приводится по: Игнатьева В. Б. Национальный состав населения Якутии... С. 34.

14 Приводится по: Расиветаев M.K. Очерки по экономике и общественному быту у якутов. Л., 1932. С. 125.

15 Приводится по: Аргунов И. А. Социальное развитие якутского народа... С. 81-82.

16 Приводится по: Алексеев $E . E$. Федеративный центр и автономия: на примере Якутской ACCP (1917-1941 гг.). Якутск, 2000. С. 229; Якутия за 50 лет в цифрах. Якутск, 1967. С. 137.

17 Горохов С. Н. История интеллигенции в Якутии (1917-1925 гг.): автореф. дис. ... канд. ист. наук. Томск, 1970. С. 5, 9.

18 Российский государственный исторический архив. Ф. 1291. Оп. 84. Д. 15. Л. 330.

19 См. об этом: Алексеев $E . E$. Федеративный центр и автономия... С. 95.

20 Там же. С. 102-103.

21 Иванова Т. С. Основные этапы общественно-политического и государственного развития Якутии в составе России (XIX в. - 30-е гг. ХХ в.). М., 2000. С. 88-98.

22 Нации и национализм... С. 146.

23 См. об этом: Федоров М.M. Развитие советской государственности в Якутии (19181937 гг.). Якутск, 1968. С. 106-112; Макаров Г. Г. Северо-Восток РСФСР в 1918-1921 гг. Якутск, 1988. С.128-136; Башарин Г.П. Общественно-политическая обстановка в Якутии в 19211925 гг. Якутск, 1996. С. 86-94; Иванова Т. С. Основные этапы... С. 101-104.

24 См. об этом: Федоров М.M. Развитие советской государственности... С. 114-116; Иванова Т. С. Основные этапы... С. 105-106.

25 См. об этом: Башарин Г.П. Общественно-политическая обстановка... С. 162; Алексеев E. E. Федеративный центр и автономия... С. 194-195.

26 Национальный архив Республики Саха (Якутия) (далее - НА РС (Я)). Ф. 460. Оп. 1. Д. 1. Л. 22 .

27 Собрание узаконений и распоряжений Рабочего и Крестьянского правительства. Отдел I. № 30. Ст. 370. 
28 См. об этом: История Бурятии: в 3 т. Т. 3. Улан-Удэ, 2011. С. 40.

29 См. об этом: Малыщиева Е.П. Национально-государственное строительство в Южной Сибири в 1917-1941 гг.: история, опыт, проблемы. Абакан, 2011. С.93, 113

30 См. об этом: Федоров М.M. Развитие советской государственности... С. 145-146, 160161; Иванова Т. С. Основные этапы... С. 110-111; Алексеев E. E. Федеративный центр и автономия... С. 202-203.

31 См. об этом: Федоров M. М. Развитие советской государственности... С. 127-128; Aлексеев E. E. Федеративный центр и автономия... С. 205-207; Иванова Т. С. Основные этапы... С. 111, 113.

32 См. об этом: Антонов Е.П. Дискуссия о территориальных границах Якутской АССР в 20-х годах // Исторические исследования в Республике Саха (Якутия): поиски и проблемы. Якутск, 1999. С.179-184; Федорова E.H., Пахолов E.A. Административно-территориальное устройство Якутии: прошлое и настоящее. Новосибирск, 2011. С. 60-63.

${ }^{33}$ См. об этом: Федоров М. М. Развитие советской государственности... С. 163-165; Иванова Т. С. Основные этапы... С. 107; Федорова E. Н. Население Якутии... С. 63-64.

34 См. об этом: История Коми с древнейших времен до конца XX века: в 2 т. Т. 2. Сыктывкар, 2004. С. 282-299.

35 Антонов E.П. Охотское побережье в контексте управленческих решений 1920-х гг.: позиции якутского руководства // Вестник Новосиб. гос. ун-та. Сер. История, фрилология. 2006. Т.5, вып. 1. С. 95.

36 Правда. 1928. 11 авг.

37 Собрание узаконений РСФСР. 1930. № 48. Ст. 582.

38 См. об этом: Шейнис В.Л. Образование СССР и его первая Конституция // Российская история. 2010. № 1. С. 74, 79.

39 См. об этом: Иванова Т. С. Основные этапы... С. 158.

40 См. об этом: Национальная политика России: история и современность. М., 1997. C. 288 .

41 См. об этом: Федорова E. Н. Население Якутии... С. 68.

42 См. об этом: История Бурятии. Т. 3. С. 137-138.

43 Иванова Т. С. Основные этапы... С. 143, 145-154, 156.

44 Государственный архив Российской Федерации. Ф.1318. Оп. 1. Д. 6. Л.110; Сборник постановлений и распоряжений рабочего и крестьянского правительства ЯАССР. 1923. С.60. Федоров М. М. Развитие советской государственности... С. 216-217.

45 Сборник постановлений и распоряжений рабочего и крестьянского правительства ЯАССР. 1924. № 1. С. 19.

46 Сборник постановлений и распоряжений рабочего, хамначчитского и крестьянского правительства ЯАССР. 1929. № 11. С. 15-17.

47 Всесоюзная перепись населения 1926 г. М., 1930. С. 237-238.

48 Миллер А. Империя Романовых и национализм: эссе по методологии исторического исследования. М., 2008. С. 93-94.

49 ЦК РКП (б) - ВКП (б) и национальный вопрос: в 2 кн. Кн. 2. 1933-1945 гг. М., 2009. С. 91; НА РС (Я). Ф.50. Оп. 1. Д. 4042. Л. 32, 139.

${ }^{50}$ Алексеев E.E. Федеративный центр и автономия... С. 231; НА РС (Я). Ф. 1081. Оп. 1. Д. 44. Л. 11.

51 См., напр.: Sehen Bolo. Lienege nuuca kelien innineegi sakha ologo [Прошлое якутов до прихода русских на Лену]. Jokuuskai, 1938 (на якутском яз.).

${ }_{52}$ См. об этом: Хиара Н.И. Из опыта национально-государственного строительства в СССР (1920-1930-е гг.) // Отечественная история. 2006. № 3. С. 138.

53 См. об этом: Национальная политика России: история и современность. С. 288.

${ }_{54}$ См. об этом: Малыциева Е. П. Национально-государственное строительство... С. 181.

55 Аршаруни А. М. В борьбе с националистической идеологией // Коммунистическая револющия. 1927. № 6. С. 30-36.

56 См. об этом: Алексеев E. E. Федеративный центр и автономия... С. 238-244.

57 Там же. С. 248-251. 
58 См. об этом: Иванова Т. С. Основные этапы... С. 158-173; Алексеев E. Е. Федеративный центр и автономия... С. 251-258.

59 Постановление ЦК ВКП (б) «О положении в Якутской организации» // Коллективизация сельского хозяйства Якутской АССР (1928-1940 гг.): документы и материалы. Якутск, 1978. C. 24-26; Алексеев E. E. Федеративный центр и автономия... С. 260-261.

60 См. об этом: Алексеев E. E. Федеративный центр и автономия... С. 274-309.

61 Иванова Т. С. Основные этапы... С. 175-188, 192.

62 См. об этом: Васильева Н.Д. Шаманство в Якутии. 1920-1930-е гг.: авторед. дис. ... канд. ист. наук. Якутск, 1998. С. 10.

63 Приводится по: Николаев А.П. Православная церковь и шаманы в Якутии (XVIIXIX вв.). Борьба с шаманизмом в Якутии // Язычество якутов. URL: http://www.yakutskhistory. net/язычество якутов/ (дата обращения: 14.05.2017); Харитонова В. Политика, корректирующая традиции: (нео)шаманы и (нео)шаманизм в СССР и РФ (1922-2010 гг.) // Narodnosti politika na teritoriu byvaleho SSSR. Praha, 2010. C. 93.

64 Васильева Н.Д. Шаманство в Якутии... С. 12; НА РС (Я). Ф.Р-50. Оп. 1. Д. 93. Л. 141; Д. 131. Л. 5; Ф.Р-52. Оп. 1. Д. 11. Л. 66; Ф.Р-60. Оп. 1. Д. 259. Л. 1-2, 5-7.

65 См. об этом: Николаев А. П. Православная церковь и шаманы...

66 История государства и права СССР: сб. документов: в 2 т. Ч. 2. М., 1968. С. 320.

67 О признаках кулацких хозяйств на Севере // Автономная Якутия. 1930. 11 июля.

68 См. об этом: Васильева Н.Д. Шаманство в Якутии... С. 13; Николаев А. П. Православная церковь и шаманы...

69 См. об этом: Васильева Н.Д. Шаманство в Якутии... С. 13.

70 Там же. С. 14-15; Николаев А. П. Православная церковь и шаманы...

71 См. об этом: Николаев А. П. Православная церковь и шаманы...

72 См. об этом: Васильева Н.Д. Шаманство в Якутии... С. 12.

73 См. об этом: История Бурятии. Т. 3. С. 45-46.

74 Собрание узаконений РСФСР. 1918. № 18. Ст. 263.

75 Приводится по: Юрганова И.И. Православие в Советской Якутии // Сибирь: история и современность. Правовые, экономические и исторические аспекты развития. Новосибирск, 2008. C. 357.

76 Филиал Национального архива РС (Я). Ф. 4. Оп. 2. Д. 656. Л. 5-6.

77 Юрганова И.И. Православие в Советской Якутии. С. 363, 364, 366.

78 Там же. С. 367-368.

79 Приводится по: Федоров М. М. Развитие советской государственности... С. 40.

80 Всесоюзная перепись населения 1939 г. Основные итоги. М., 1992. С. 189.

81 Приводится по: Игнатьева В. Б. Национальный состав населения Якутии... С. 39-42.

82 Приводится по: Аргунов И.А. Социальное развитие якутского народа... С. 48.

83 Приводится по: Там же. С. $34,42$.

84 Сталин И. В. Сочинения: в 13 т. Т. 10. М., 1949. С. 69.

85 См. об этом, напр.: Вдовин А. И. Эволюция национальной политики СССР // Вестник Московского университета. Сер. 8. История. 2002. № 1. С. 21; ЦК РКП(б) - ВКП(б) и национальный вопрос. Кн.2. С.6; Русские в ХХ веке. М., 2004. С.97; Мальцшева Е. П. Национально-государственное строительство... С. 165-179.

Статья поступила в редакцию 27 мая 2017 г. Рекомендована в печать 3 декабря 2018 г.

\section{ДЛЯ ЦИТИРОВАНИЯ}

Борисов А. А. Исторический опыт нациестроительства в Якутии (1922 - конец 1930-х гг.) // Новейшая история России. 2019. Т. 9, № 1. С. 214-232. https://doi.org/10.21638/11701/ spbu24.2019.113 УДК 94:323.1(571.56) 
Аннотация: В статье впервые рассматривается проблема нациестроительства в Якутии с 1922 г. по конец 1930-х гг. Крупнейшая этническая общность в данном регионе стала субъектом глобального процесса активизации национальных движений на месте распавшихся многонациональных империй Европы и Азии под влиянием результатов Первой мировой войны и революций. В этом политическом и культурном проекте участвовали как центральные власти РСФСР и СССР, так и руководство созданной в 1922 г. Якутской АССР. Сложившиеся предпосылки для формирования якутской нации (общность исторической судьбы, единство языка, наличие национальной интеллигенции и т.д.) и политическая борьба между сторонниками централизации и федерализма форсировали создание необходимых национальных атрибутов (автономии, письменной национальной литературы, национальной модернизированной культуры и экономики). Несомненны успехи, достигнутые в результате проведения национальной политики с учетом местных особенностей: временное примирение и сотрудничество с беспартийной интеллигенцией; толерантность к верующим, среди которых в большинстве были якуты; создание массовой письменности. Вместе с тем успехи скрадывались поспешностью в темпах модернизации и повышения культурного уровня якутского населения (скачкообразными преобразованиями в экономике, политическими амбициями части интеллектуальной элиты якутского общества, не подкрепленными объективными условиями, подстегиванием коренизации) до уровня ведущих наций. В якутском нациестроительстве выделяются две фазы: 1922 - конец 1920-х гг.; конец 1920-х гг. - конец 1930-х гг. Эти фазы соответствуют стадиям преобладания национальной тенденции и перехода к безнациональной политике. Главные итоги и уроки нациестроительства названного времени двояки: усеченная автономия - но при этом опыт национального государственного управления (удачный опыт внутреннего районирования и компромисс в определении границ ЯАССР); разгром национальной интеллигенции старой формации - но при этом создание массовой национальной письменности; гонения на религию и традиционные верования и их вытеснение - но при этом повышение общего культурного уровня.

Ключевые слова: нациестроительство, якуты, этноконфессиональная политика, национализм, автономия, СССР, Якутия.

Исследование выполнено при финансовой поддержке РНФ в рамках проекта № 15-18-00119 «Исторический опыт управления этническим разнообразием и этноконфессиональными конфликтами в имперской, советской и постсоветской России: междисциплинарное исследование».

Сведения об авторе: Борисов А. А. - д-р ист. наук, приглашенный исследователь, Санкт-Петербургский Институт истории Российской академии наук; гл. науч. сотр., Институт гуманитарных исследований и проблем малочисленных народов Севера СО РАН (Якутск, Россия); a_a_borisov@mail.ru

Санкт-Петербургский институт истории РАН, Россия, 197110, Санкт-Петербург, Петрозаводская ул., 7 Институт гуманитарных исследований и проблем малочисленных народов Севера СО РАН, Россия, 677027, Якутск, ул. Петровского, 1

\section{FOR CITATION}

Borisov A. A. 'The Historical Experience of Nation-Building in Yakutia (1922 to the late 1930s)', Modern History of Russia, vol.9, no. 1, 2019, pp.214-232. https://doi.org/10.21638/11701/ spbu24.2019.113 (In Russian)

Abstract: This article provides one of the first studies of nation-building in Yakutia from 1922 to the end of the 1930s. The largest ethnic community in this region became the subject of a global process of activating national movements at the site of disintegrated multinational empires of Europe and Asia under the influence of the First World War and subsequent revolutions. This political and cultural project involved both the central authorities of the RSFSR and the USSR, as well as the leadership of the Yakut ASSR, established in 1922. The existing preconditions for the formation of a Yakut nation (commonality of historical destiny, unity of language, existence of a national intelligentsia, etc.) and the political struggle between supporters of centralization and federalism forced the creation of necessary national attributes (autonomy, written national literature, national modernized culture and economy). There were some clear successes achieved by national policies, taking into account local peculiarities 
(e.g. temporary reconciliation and cooperation with non-partisan intelligentsia, tolerance for believers, most of whom were Yakuts, and creation of mass written language). At the same time, they were hindered by haste in modernizing and raising the cultural level of the Yakut population (spasmodic economic transformation, political ambitions by part of the Yakut intelligentsia not supported by objective conditions, thus encouraging indigenization) Yakutia's nation-building had two phases: phase 1 (1922 to the end of the 1920s), and phase 2 (late 1920s to the end of the 1930s), which corresponded to stages of prevalence of the national trend and the transition to non-national politics. Among the main results and lessons of nation-building were: truncated autonomy, but the experience of national government (successful experience of internal regionalization and defining the boundaries of the YASSR), defeat of the old national intelligentsia, creation of mass national writing, repression of religion and traditional beliefs, and raising the general cultural level).

Keywords: nation-building, Yakuts, ethno-confessional politics, nationalism, autonomy, USSR, Yakut ASSR.

This research was supported by "Russian Science Foundation", project no. 15-18-00119 "Historical Experience in Governance of Ethnic Diversity and Ethno-Confessional Conflicts in Imperial, Soviet, Post-Soviet Russia: an Interdisciplinary Study".

Author: Borisov A. A. - Dr. Sci. in History, Visiting Researcher, St. Petersburg Institute of History, Russian Academy of Sciences; Senior Research Fellow, Institute for Humanities Research and Indigenous Studies of the North, Siberian Branch of the Russian Academy of Sciences (Yakutsk, Russia); a_a_borisov@mail.ru

St. Petersburg Institute of History of the Russian Academy of Sciences, 7, Petrozavodskaya st., St. Petersburg, 197110, Russia

Institute for Humanities Research and Indigenous Studies of the North, Siberian Branch of the Russian Academy of Sciences, 1, Petrovskogo st., Yakutsk, 677007, Russia

\section{References:}

Achkasov V. A. Etnopolitologiya (St. Petersburg, 2005).

Alekseev E. E. Federativnyi tsentr i avtonomiya: na primere Yakutskoi ASSR (1917-1941 gg.) (Yakutsk, 2000).

Antonov E. P. 'Diskussiya o territorial'nykh granicakh Yakutskoi ASSR v 1920-kh godakh', Istoricheskie issledovaniya v respublike Sakha (Yakutiya): poiski i problemy (Yakutsk, 1999).

Antonov E. P. 'Okhotskoe poberezhie v kontekste upravlencheskikh reshenii 1920-kh gg.: pozitsii yakutskogo rukovodstva', Vestnik Novosib. gos. un-ta. Ser. Istoriya, filologiya, vol. 5, no. 1, 2006.

Argunov I. A. Socialnoe razvitie yakutskogo naroda (istoriko-sociologicheskoe issledovanie obraza zhizni) (Novosibirsk, 1985).

Arsharuni A. M. 'V bor'be s natsionalisticheskoi ideologiey', Kommunisticheskaya revoliutsiya, no. 6, 1927.

Basharin G. P. Obshchestvenno-politicheskaya obstanovka v Yakutii v 1921-1925 gg. (Yakutsk, 1996).

Borisov A. 'The political status and ethnic identity of Siberian nomadic "aliens" in the first half of the $19^{\text {th }}$ century', Northeast Asian Studies, Vol. 18, 2014.

Borisov A. A. 'Ulus kak universaljnaya forma politicheskoi i obshchestvennoi samoorganizacii tjurkskikh i mongol'skikh narodov', Eurasian Nomadic Pastoralism History, Culture, Environment (Sendai, 2016).

Bromley Yu. V. Etnosocialnye protsessy: teoriya, istoriya, sovremennost (Moscow, 1987).

CK RKP(b) - VKP(b) i nacionalnyi vopros, Book 2: 1933-1945 (Moscow, 2009).

Fedorov M. M. Razvitie sovetskoi gosudarstvennosti v Yakutii (1918-1937 gg.) (Yakutsk, 1968).

Fedorova E. N. Naselenie Yakutii: proshloe i nastoyashchee (geodemograficheskoe issledovanie) (Novosibirsk, 1999).

Fedorova E. N., Pakhomov E. A. Administrativno-territorialnoe usrtoistvo Yakutii: proshloe i nastoyashchee (Novosibirsk, 2011).

Gorokhov S. N. Istoriya intelligencii v Yakutii (1917-1925 gg.). [Candidate of History Dissertation] (Tomsk, 1970). Ignatieva V. B. Natsionalnyi sostav naseleniya Yakutii (etno-statisticheskoe issledovanie) (Yakutsk, 1994).

Istoriya Buryatii, Vol. 3 (Ulan-Ude, 2011).

Istoriya Komi s drevneushikh vremen do kontsa XX veka, Vol. 2 (Syktyvkar, 2004).

Ivanova T.S. Osnovnye etapy obshchestvenno-politicheskogo i gosudarstvennogo razvitiya Yakutii $v$ sostave Rossii (XIXv. - 30-e gg. XXv.) (Moscow, 2000).

Kappeler A. Rossiya - mnogonacionaljnaya imperiya (Moscow, 2000). 
Kharitonova V. 'Politika, korrektiruyushchaya tradicii: (neo) shamany i (neo) shamanizm v SSSR i RF (19222010 gg.)', Nacionalnaya politika na territorii byvshego SSSR (Prague, 2010).

Khmara N. I. 'Iz opyta nacional'no-gosudarstvennogo stroitel'stva v SSSR (1920-1930-e gg.)', Otechestvennaya istoriya, no. 3, 2006.

Ksenofontov G. V. Elleiyada. (Moscow, 1977).

Makarov G. G. Severo-Vostok RSFSR v 1918-1921 gg. (Yakutsk, 1988).

Mamysheva E. P. Nacionalno-gosudarstvennoe stroitel'stvo v Yuzhnoi Sibiri v 1917-1941 gg.: istoriya, opyt, problemy (Abakan, 2011).

Miller A. Imperiya Romanovykh I natsionalizm: esse po metodologii istoricheskigo issledovaniya (Moscow, 2008).

Nacionalnaya politika Rossii: istoriya i sovremennost (Moscow, 1997).

Natsii i natsionalizm, B. Anderson, O. Bauer, M. Khrokh et al. (Moscow, 2002).

Nikolaev A. P. 'Pravoslavnaya tserkov'i shamany v Yakutii (XVII-XIX vv.). Bor'ba s shamanizmom v Yakutii', Yazychestvo yakutov. Available at: http://www.yakutskhistory.net/yazychestvo yakutov (accessed: 14.05.2017).

Novgorodov S. A. 'K voprosu o govorakh v yakutskom yazyke', Pervye shagi yakutskoi pismennosti: statii i pisma (Moscow, 1977).

Rastsvetaev M. K. Ocherki po ekonomike i obshchestvennomu bytu u yakutov (Leningrad, 1932).

Russkie vXX veke (Moscow, 2004).

Sehen Bolo. Lienege nuuca kelien innineegi sakha ologo (Yakutsk, 1938).

Semenov Yu. I. 'Socialno-istoricheskie organizmy, etnosy, nacii', Etnograficheskoe obozrenie, no. 3, 1996.

Sheinis V. L. 'Obrazovanie SSSR i ego pervaya Konstituciya', Rossiyskaya istoriya, no. 1, 2010.

Sokolov M. P. Yakutskaya guberniya po perepisi 1917 goda. (Irkutsk, 1922).

Stalin I. V. Sochineniya, Vol. 10 (Moscow, 1949).

Tishkov V. A. O natsii. Available at: http://www.valerytishkov.ru/cntnt/publikacii3/publikacii/o_nacii 1.html (accessed: 23.05.2017).

Vasilyeva N. D. Shamanstvo v Yakutii. 1920-1930-e gg. [Candidate of History Dissertation] (Yakutsk, 1998).

Vdovin A. I. 'Evoluciya nacionalnoi politiki SSSR', Vestnik Moskovskogo universiteta. Ser. 8. Istoriya, no. 1, 2002. Vlast' i reformy. Ot samoderzhavnoi k Sovetskoi Rossii. (Moscow, 2006).

Voronkin M.S. Dialektnaya sistema yazyka sakha: obrazovanie, vzaimodeistvie, s literaturnym yazykom i kharakteristika (Novosibirsk, 1999).

Vsesoyuznaya perepis naseleniya $1926 \mathrm{~g}$. (Moscow, 1930).

Vsesoyuznaya perepis naseleniya $1939 \mathrm{~g}$. Osnovnye itogi (Moscow, 1992).

Yakutiya za 50 let $v$ tsifrakh (Yakutsk, 1967).

Yurganova I. I. 'Pravoslavie v Sovetskoi Yakutii', Sibir: istoriya i sovremennost. Pravovye, ekonomicheskie $i$ istoricheskie aspekty razvitiya (Novosibirsk, 2008).

Received: May 27, 2017

Accepted: December 3, 2018 